Int. J. Dev. Biol. 63: 589-595 (2019)

https://doi.org/10.1387/ijdb.190092aw

\title{
Acrosome reaction-inducing substance triggers two different pathways of sperm intracellular signaling in newt fertilization
}

\author{
SHINNOSUKE KON', AKIO TAKAKU' ${ }^{1}$ FUBITO TOYAMA², ERIKO TAKAYAMA-WATANABE*,3 \\ and AKIHIKO WATANABE*,1 \\ ${ }^{1}$ Faculty of Science, Yamagata University, Yamagata, ${ }^{2}$ Graduate School of Engineering, Utsunomiya University, \\ Tochigi, ${ }^{3}$ Institutes of Arts and Sciences, Yamagata University, Yamagata, Japan
}

\begin{abstract}
The acrosome reaction is induced in the sperm of Cynops pyrrhogaster immediately in response to a ligand protein called acrosome reaction-inducing substance (ARIS) in the egg jelly at fertilization, whereas a spontaneous acrosome reaction occurs time-dependently in correlation with the decline of sperm quality for fertilization. The ARIS-induced acrosome reaction was recently found to be mediated by TRPV4 in association with the NMDA type glutamate receptor, although the intracellular mediators for the acrosome reaction are largely unclear. In the present study, spontaneous acrosome reaction was significantly inhibited by $\mathrm{Ni}^{2+}, \mathrm{RN} 1734$, and diltiazem, which blocks Cav3.2, TRPV4 or TRPM8, and the cyclic nucleotide-gated channel, respectively. In contrast, expression of $\mathrm{Ca}^{2+}$-activated transmembrane and soluble adenylyl cyclases was detected in the sperm of $\boldsymbol{C}$. pyrrhogaster by reverse transcription-polymerase chain reaction. Activator of transmembrane or soluble adenylyl cyclases (forskolin or $\mathrm{HCO}_{3}^{-}$) independently promoted spontaneous acrosome reaction, while an inhibitor of each enzyme (MD12330A or KH7) inhibited it only in the sperm with high potential for spontaneous acrosome reaction. An inhibitor of protein kinase A (H89) inhibited spontaneous acrosome reaction in a manner independent of sperm potential for spontaneous acrosome reaction. Surprisingly, KH7 significantly inhibited ARIS-induced acrosome reaction, but its effect was seen in a small percentage of sperm. H89 had no effect on ARIS-induced acrosome reaction. These results suggest that $C$. pyrrhogaster sperm possess multiple intracellular pathways for acrosome reaction, involving $\mathrm{Ca}^{2+}$ permeable channels, adenylyl cyclases and PKA, and that two pathways having distinct dependencies on adenylyl cyclases may contribute to ARISinduced acrosome reaction at fertilization.
\end{abstract}

KEY WORDS: acrosome reaction, $\mathrm{Ca}^{2+}$ channel, adenylyl cyclase, PKA, sperm, urodele

\section{Introduction}

Sperm acrosome reaction (AR) is a critical event for the success of fertilization in many animal species. It is mediated by intracellular $\mathrm{Ca}^{2+}$ and cyclic adenosine monophosphate (cAMP) (Buffone et al., 2014; Vacquier et al., 2014), both of which are increased in response to a variety of extracellular triggers depending on the species (SeGall and Lennarz, 1979; Ikadai and Hoshi, 1981; Cherr and Clark, 1985; Thomas and Meizel, 1989; Ueda et al., 2002, 2003; Sasanami et al., 2003, 2007; Okumura et al., 2004). The wide variation of the triggers suggests that the signaling pathway for the AR has been modified multiple times during animal evolution.
The acrosome reaction of amphibian sperm is induced by a glycoprotein called acrosome reaction-inducing substance (ARIS) on the surface of egg jelly (Picheral, 1977; Campanella et al., 1997; Sasaki et al., 2002) or in the vitelline envelope (Ueda et al., 2002;

\footnotetext{
Abbreviations used in this paper: AR, acrosome reaction; ARIS, acrosome reactioninducing substance; cAMP, cyclic adenosine monophosphate; CNG, cyclic nucleotide-gated; JE, egg jelly extract; NMDAR, N-methyl D-aspartate-type glutamate receptor; PKA, protein kinase A; RT-PCR, reverse transcription polymerase chain reaction; ST, Steinberg's salt solution; TRPM8, transient receptor potential melastatin 8; TRPV4, transient receptor potential vanilloid 4; VDCG voltage-dependent $\mathrm{Ca}^{2+}$ channel
}

\footnotetext{
*Address correspondence to: Eriko Takayama-Watanabe. Institute of Arts and Science, Yamagata University, 1-4-12 Kojirakawa, Yamagata, 9908560 Japan. Tel: +81-628-4802. E-mail: ewatanabe@kdw.kj.yamagata-u.ac.jp - iD https://orcid.org/0000-0001-5950-6207 or

Akihiko Watanabe. Faculty of Science, Biological division, Yamagata University, 1-4-12 Kojirakawa, Yamagata, 9908560 Japan. Tel: +81-628-2619.

e-mail: watan@sci.kj.yamagata-u.ac.jp - (iD) https://orcid.org/0000-0002-0382-5433
}

Supplementary Material for this paper is available at: https://doi.org/10.1387/ijdb.190092aw

Submitted: 27 May, 2019; Accepted: 3 October, 2019; Edited by: Makoto Asashima

ISSN: Online 1696-3547, Print 0214-6282

(C) 2019 UPV/EHU Press

Printed in Spain 
Barisone et al., 2002). In the Japanese red-bellied newt, Cynops pyrrhogaster, ARIS is co-localized with a sperm motility-initiating substance on the egg jelly surface to construct a unique mechanism of acrosome reaction-associated initiation of sperm motility (Watanabe et al., 2009; Watanabe et al., 2010; Takayama-Watanabe et al., 2014; Yokoe et al., 2016). For the success of internal fertilization of the newt, it is critical for sperm to undergo AR on the egg jelly surface, since ectopic induction of AR severely decreases the fertilization efficiency (Takahashi et al., 2006). On the other hand, sperm of this newt have the potential to undergo a spontaneous acrosome reaction (Kon et al., 2017). This potential is enhanced during storage in the vas deferens and time-dependently manifested in the presence of $\mathrm{Ca}^{2+}$ and $\mathrm{pH}$ at levels similar to those in egg jelly. Although spontaneous AR is a risk for declining fertilizability of the newt sperm, it is known to occur in mammalian capacitated sperm (Visconti et al., 1999), suggesting that spontaneous AR may be a fundamental feature of sperm in internally fertilizing vertebrates. In mice, sperm possess an another signaling pathway for the induction of AR that is triggered by a glycoprotein of the zona pellucida (Bleil and Wassarman, 1980). Although which pathway works at fertilization is controversial (Jin et al., 2011), spontaneous AR may work as a substitute of species-specific signaling pathway for the induction of $A R$ in evolution. However, the relationship between the signaling pathways for ligand-induced AR and spontaneous AR has not been evaluated in correlation with the evolution of the regulatory mechanism underlying the induction of $A R$.

Sperm of $C$. pyrrhogasterpossess multiple types of $\mathrm{Ca}^{2+}$ permeable channels including T-type and L-type voltage-dependent $\mathrm{Ca}^{2+}$ channels (VDCC; Cav3.2, 1.1, and 1.2), transient receptor potential vanilloid 4 (TRPV4), TRP melastatin 8 (TRPM8) and N-methyl D-aspartate-type glutamate receptor (NMDAR) (Watanabe and Takayama-Watanabe, 2014; Endo et al., 2019). TRPV4 mediates the induction of AR by ARIS in association to NMDAR (Endo et al., 2019), although it is largely unknown which channel participates in

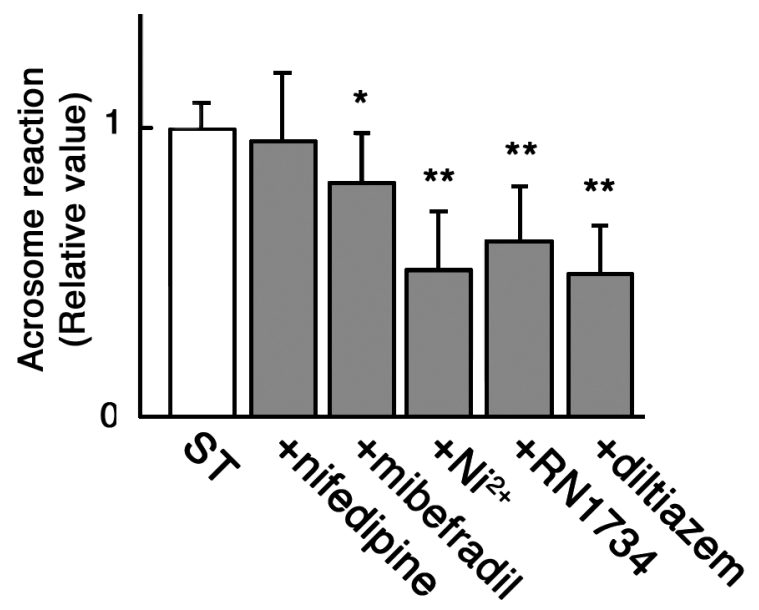

Fig. 1. Effects of blockers of $\mathrm{Ca}^{2+}$ permeable channels on spontaneous AR. Sperm were incubated in Steinberg's salt solution (ST) containing a blocker of $\mathrm{Ca}^{2+}$ permeable channel for $1 \mathrm{~h}$ and fixed by glutaraldehyde. The acrosome reaction was evaluated by the absence of acrosome in the tip of the sperm head using a dark field microscope. Percentages of the acrosome reacted sperm were expressed by relative values against a mean percentage of them in ST. Asterisks indicate significant differences against $S T\left({ }^{*} P<0.01\right)$.
TABLE 1

\section{CNGB3 CDNA DETECTED BY THE RNASEQ FROM SPERMATOGENIC TESTES OF C. PYRRHOGASTER}

\begin{tabular}{lllccc} 
genes & accession & species & bit score & E-value & identical (\%) \\
\hline comp24190 & gil345326098 & Ornithorhynchus anatinus & 137.5 & $3.75 \mathrm{E}-33$ & 45.7 \\
& gil397501025 & Pan paniscus & 131 & $2.09 \mathrm{E}-30$ & 44.8 \\
& gil114620818 & Pan troglodytes & 129 & $7.87 \mathrm{E}-30$ & 42.5 \\
\hline
\end{tabular}

spontaneous AR. Whereas, cyclic nucleotide-gated (CNG) channel is sometimes critical for AR in other species (Darszon et al., 2008). Although its involvement in the induction of AR is not examined in the newt sperm, an analogue of cAMP can induce the AR (Kon et al., 2017). In the present study, to consider the possible evolutional correlation between intracellular signaling pathways of spontaneous and ligand-induced ARs, we characterized $\mathrm{Ca}^{2+}$ permeable channels, and downstream mediators with focusing to adenylyl cyclases and cyclic AMP-dependent protein kinase (PKA), in the spontaneous $A R$ and ARIS-induced AR of $C$. pyrrhogaster sperm.

\section{Results}

\section{$\mathrm{Ca}^{2+}$ permeable channels in spontaneous acrosome reaction}

In order to examine the participation of $\mathrm{Ca}^{2+}$ permeable channels of $C$. pyrrhogaster sperm in spontaneous AR, sperm were treated with a channel blocker for $1 \mathrm{~h}$ in Steinberg's salt solution (ST) that was modified to have a $\mathrm{Ca}^{2+}$ concentration and $\mathrm{pH}$ equivalent to those in egg jelly (Ukita et al., 1999). Spontaneous AR that occurred in $24 \pm 0.82 \%$ of the sperm in ST was significantly suppressed by a blocker of T type VDCC (mibefradil), a selective blocker of Cav3.2 $\left(\mathrm{Ni}^{2+}\right)$, or by a blocker of TRPV4 and TRPM8 (RN1734) (Endo et al., 2019) (Fig. 1). A blocker of L-type VDCC (nifedipine) showed no effect. Spontaneous AR is recently shown to be inhibited by a blocker of NMDAR (MK801) (Endo et al., 2019). These results suggest that spontaneous AR occurs through the gating of T-type VDCC, TRPV4 (orTRPM8), and NMDAR. T type VDCC possibly present in the sperm of $C$. pyrrhogaster is Cav3.2 (Watanabe and Takayama-Watanabe, 2014). In addition, we examined the involvement of CNG channel in the spontaneous AR. RNAseq from spermatogenic testes included a contig sequence with high homology to the CNGB3 subunit of CNG channel (Table 1). The CNGB3 gene was abundantly expressed in the spermatogenic testes compared to the nonspermatogenic testes (Supplementary Fig. S1), suggesting the possible presence of the CNG channel in sperm. Spontaneous AR was inhibited by a blocker of the CNG channel (diltiazem) (Fig. 1). This result suggests that the CNG channel also mediates the spontaneous AR.

\section{Adenylyl cyclases in spontaneous acrosome reaction}

RNAseq of the spermatogenic testes included contigs with high homology to transmembrane adenylyl cyclases, AC-3, -6, -9 (Table 2), and soluble AC, AC-10. RT-PCR analysis showed the abundant expression of $A C$-3 gene in spermatogenic testes and the equivalent expression of the gene of the other three adenylyl cyclases between spermatogenic and nonspermatogenic testes (Fig. 2). Acrosome reacted sperm that were $25 \pm 6.3 \%$ of total sperm in ST were increased by forskolin and $\mathrm{HCO}_{3}^{-}$that are activators of the transmembrane and soluble adenylyl cyclases, respectively (Chen et al., 2000; Wertheimer et al., 2013) (Fig. 3A). In addition to the acrosome reacted sperm, sperm having a granular vesicle at the tip of sperm head were often observed, which suggests that spontane- 
TABLE 2

ADENYLYL CYCLASE CDNAS DETECTED BY THE RNASEQ FROM SPERMATOGENIC TESTES OF C. PYRRHOGASTER

\begin{tabular}{lllccc} 
genes & accession & species & bit score & E-value identical (\%) \\
\hline AC3 & & & & & \\
comp52271 & gil156717224 & Xenopus (Silurana) tropicalis & 1936 & 0 & 96.2 \\
& gil348534829 & Oreochromis niloticus & 1810 & 0 & 91.7 \\
& gil363732440 & Gallus gallus & 1806 & 0 & 92.1 \\
AC6 & & & & & \\
comp54794 & gil2734867 & Takifugu rubripes & 815.5 & 0 & 87.4 \\
& gil444515388 & Tupaia chinensis & 799.7 & 0 & 86.8 \\
& gil351697635 & Heterocephalus glaber & 798.9 & 0 & 86.6 \\
AC9 & & & & & \\
comp57215 & gil449278870 & Columba livia & 2024 & 0 & 85.0 \\
& gil432111555 & Myotis davidii & 1945 & 0 & 83.4 \\
& gil440901440 & Bos grunniens mutus & 1940 & 0 & 83.6 \\
AC10 & & & & & \\
comp55328 & gil169261973 & Squalus acanthias & 185.3 & $4.19 \mathrm{E}-51$ & 80.9 \\
& gil465976920 & Chelonia myda & 177.9 & $5.25 \mathrm{E}-48$ & 74.8 \\
& gil444435659 & Bos taurus & 161.8 & $2.63 \mathrm{E}-44$ & 71.9 \\
\hline
\end{tabular}

ous AR was not completed in those sperm. The effect of $\mathrm{HCO}_{3}{ }^{-}$on sperm soluble adenylyl cyclase was further confirmed by the suppression of spontaneous AR by cotreating with $\mathrm{HCO}_{3}$ and $\mathrm{KH} 7$, an inhibitor of soluble adenylyl cyclase (Supplementary Fig. S2). These results suggest that CAMP produced by those transmembrane and soluble adenylyl cyclases can mediate spontaneous AR. However, spontaneous AR was not significantly suppressed by MDL12330A, an inhibitor of transmembrane adenylyl cyclases, and KH7 (Fig. 3B). Potential of spontaneous AR is different among sperm population depending on the duration of sperm storage in the vas deferens (Kon et al., 2017). Thus, we independently analyzed the data of the sperm population that exhibited spontaneous AR at more than $20 \%$ $(30 \pm 2.9 \%)$ in ST for $1 \mathrm{~h}$ and those at less than $20 \%(19 \pm 0.91 \%)$. Both MDL12330A and KH7 significantly suppressed spontaneous AR in the sperm population with high potential (>20\% in $1 \mathrm{~h}$ incubation), while they did not suppress the spontaneous AR in the population with low potential (<20\% in $1 \mathrm{~h}$ incubation).

\section{Protein Kinase $A$ in spontaneous acrosome reaction}

Involvement of PKA was examined using a specific PKA inhibitor (H89). When sperm were incubated in ST containing H89 for $1 \mathrm{~h}$, spontaneous AR was significantly inhibited regardless of the sperm's potential for spontaneous AR (Fig. 4).
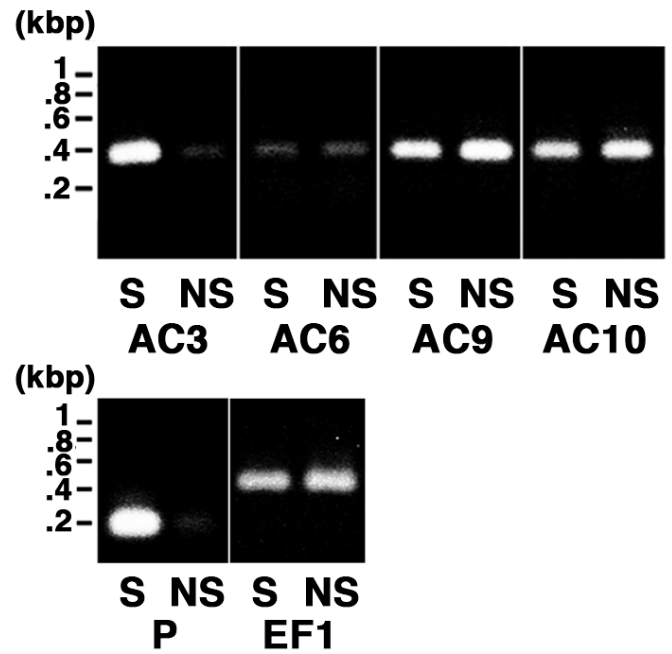

Fig. 2. Expression of mRNA for adenylyl cyclases in the spermatogenic and non-spermatogenic testis. One- $\mu$ g of total RNA purified from sper matogenic (S) and non-spermatogenic (NS) testes was reverse-transcribed, and polymerase chain reaction was performed using DNA primers specific for $A C-3,-6,-9$, and -10. Expressions of protamine (P) and elongation factor1 (EF1) mRNA were examined as controls.

\section{CNG channel, adenylyl cyclases, and PKA in ARIS-induced acrosome reaction}

Acrosome reaction-inducing substance induces AR immediately in sperm being suspended in egg jelly extract (JE) including ARIS (Hiyoshi et al., 2007). The ARIS-induced AR is mediated by TRPV4 and NMDAR (Endo et al., 2019) but not by VDCCs (Takayama-Watanabe et al., 2015). To examine the involvement of CNG channel in ARIS-induced AR, sperm were incubated in JE containing diltiazem. This blocker did not inhibit the induction of AR in JE (Fig. 5A). Next, the involvement of transmembrane and soluble adenylyl cyclases was examined in ARIS-induced AR. The acrosome reaction was significantly inhibited by $\mathrm{KH} 7$ in JE, although many sperm underwent AR (Fig. 5B). MDL 12330A also tended to decrease the induction of $A R$ in JE although the significant difference was not observed. Finally, the involvement of PKA in the ARIS-induced AR was examined using H89. That inhibitor showed no effect on the induction of AR in JE (Fig. 5C).
A

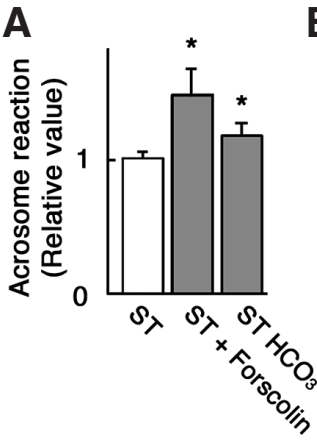

B

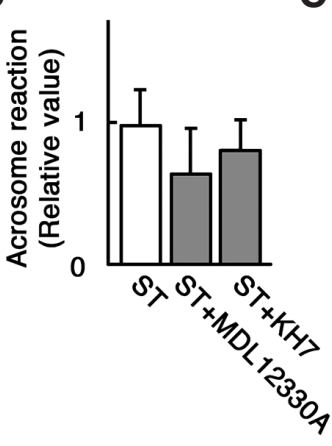

C

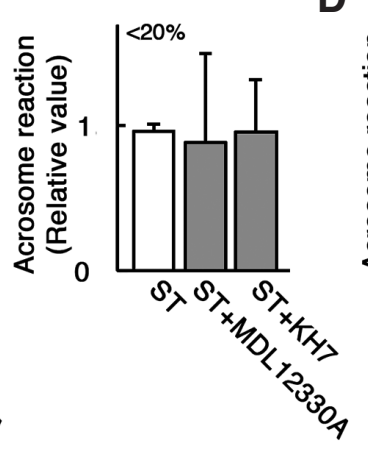

D

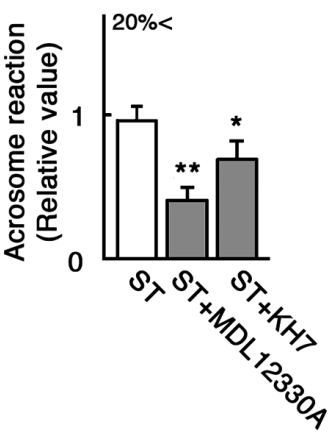

Fig. 3. Effect of adenylyl cyclase activators and inhibitors on spontaneous acrosome reaction. (A) Sperm were incubated in Steinberg's salt solution (ST) containing an activator of transmembrane adenylyl cyclase (forskolin) or soluble adenylyl cyclase $\left(\mathrm{HCO}_{3}^{-}\right)$. The acrosome reaction was evaluated by the absence of acrosome in the tip of the sperm head using a dark field microscope. Percentages of the

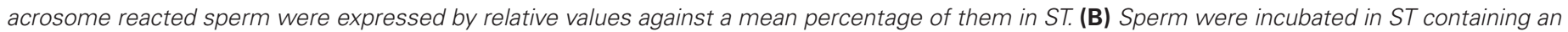

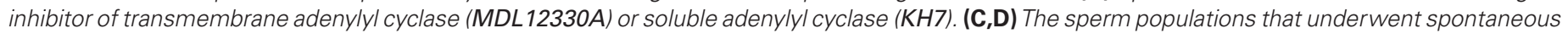

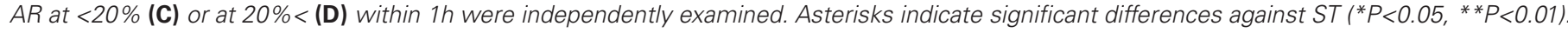




\section{Discussion}

Acrosome reaction is generally induced by the increase of intracellular $\mathrm{Ca}^{2+}$ and sperm of an identical species sometimes possess multiple intracellular signaling pathways for AR (Shur, 1999; Visconti et al., 1999; Darszon et al., 2006). Results of the present study suggest that multiple signaling pathways are also present for AR in the sperm of $C$. pyrrhogaster. Based on the results and the previous studies, they are characterized by the different dependencies on $\mathrm{Ca}^{2+}$ permeable channels, adenylyl cyclases, and PKA. Possible pathways for ARs are proposed in Fig. 6. Cav3.2 and TRPV4 are initial triggers for spontaneous AR. Those channels seem to independently gate in sperm since the spontaneous AR was not completely inhibited by blocking neither channels (Fig. 1). CNG channel is gated in the downstream of Cav3.2 and TRPV4 since $\mathrm{Ca}^{2+}$ influxed through these channels should activate $\mathrm{Ca}^{2+}$ activated adenylyl cyclases, ie. AC3 and AC10 (Choi et al., 1992; Jaiswal and Conti, 2003). Both types of adenylyl cyclases are suggested to be present in the sperm (Fig. 2). Actually, cAMP level of C. pyrrhogaster sperm is raised in ST (Kon et al., 2017). NMDAR also mediates spontaneous $\mathrm{AR}$ by the $\mathrm{Ca}^{2+}$ influx through either Cav3.2 or TRPV4 (or TRPM8) (Fig. 1), which causes depolarization of sperm membrane allowing the cation transport through the NMDAR (Aidley and Stanfield, 1996). This contrasts the fact that NMDAR works in association with not Cav3.2 but TRPV4 in the ARIS-induced AR (Takayama-Watanabe et al., 2015; Endo et al., 2019). ARIS signal appears to selectively gate TRPV4 during the fertilization process.

The activated adenylyl cyclases caused spontaneous AR only in the limited percentage of the sperm having high potential of spontaneous AR, while those having low potential did it independently of the adenylyl cyclases (Fig. 3). This indicates that sperm of $C$. pyrrhogaster possess two distinct pathways for AR regarding to the dependency on the adenylyl cyclases. Since the potential of spontaneous AR is increased when sperm are stored in the vas deferens for longer time-period (Kon etal., 2017), adenylyl cyclase-dependent pathway is thought to become active by a certain change of sperm physiology concerning a decline of sperm quality for fertilization and leading to the sensing to increasing cAMP. Unexpectedly, both
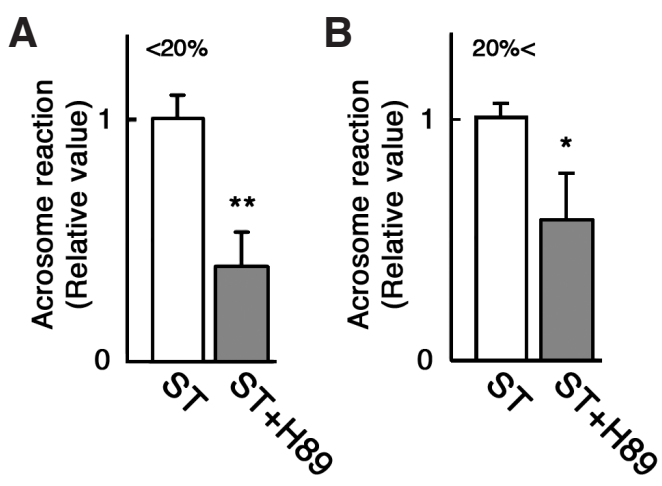

Fig. 4. Effect of a PKA inhibitor on the spontaneous acrosome reaction (AR). Sperm populations that underwent spontaneous AR at $<20 \%$ (A) or at $>20 \%$ (B) within $1 \mathrm{~h}$ were independently incubated in Steinberg's salt solution (ST) containing $\mathrm{H} 89$ for $1 \mathrm{~h}$, and then fixed by glutaraldehyde. The acrosome reaction was evaluated by the absence of acrosome in the tip of the sperm head using a dark field microscope. Asterisks indicate significant differences against $S T\left({ }^{*} P<0.05,{ }^{*} P<0.01\right)$.

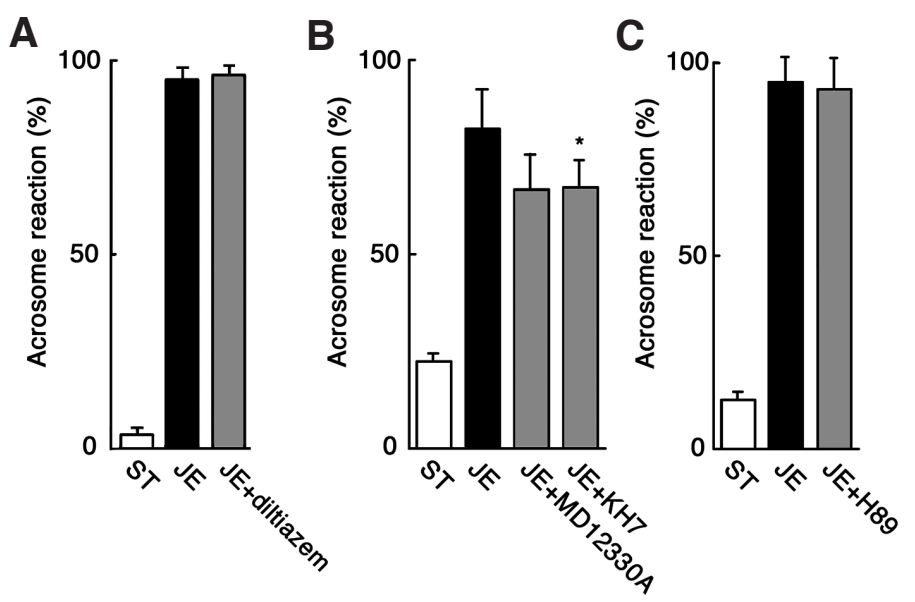

Fig. 5. Effects of inhibitors of cyclic nucleotide-gated (CNG) channel, adenylyl cyclases and PKA on ARIS-induced acrosome reaction. Sperm were pretreated with an inhibitor of CNG channel (diltiazem) (A), transmembrane or soluble adenylyl cyclases (MD12330A or KH7) (B), or PKA (H89) (C), and then incubated in JE containing ARIS and the same inhibitor for $5 \mathrm{~min}$. Acrosome reaction was evaluated by the absence of acrosome in the tip of the sperm head using a dark field microscope. Asterisk indicates a significant difference against JE $(P<0.05)$.

adenylyl cyclase-independent and -dependent pathways are also present in the downstream of ARIS (Fig. 5). It is quite unique that two distinct pathways are activated by an identical ligand, ARIS, for the AR. Since transmembrane adenylyl cyclase involves in the adenylyl cyclase-dependent pathway, ARIS may trigger that pathway through a G-protein, which is a possible mediator for the AR in mammalian sperm (Ward et al., 1992; Etkovitz et al., 2009). The adenylyl cyclase-dependent pathway in the ARIS signal is activated in the quite limited number of sperm and may also correlate with the sperm quality as it does in spontaneous AR. Supposingly, the adenylyl cyclase-dependent pathway compensates for the malfunction of adenylyl cyclase-independent one and assures the immediate response to ARIS that is crucial for sperm to participate in fertilization. The adenylyl cyclase-dependent pathways in the ARIS-induced AR and the spontaneous AR are different in the dependency on PKA (Fig. 5). This means that two of the four different pathways in the downstream of $\mathrm{Ca}^{2+}$ permeable channels are selectively activated in the sperm to cause AR during the fertilization of $C$. pyrrhgoaster.

The results of the present study suggest thatARIS limits the intracellular signaling pathways in the sperm of $C$. pyrrhogasterthrough determining the $\mathrm{Ca}^{2+}$ permeable channels and the dependency on PKA. On the other hand, co-presence of the multiple pathways for AR may give a potential to substitute one pathway for another and develop a new signaling pathway in the evolution of reproductive system. In C. pyrrhogaster, Cav3.2 does not work in the induction of $\mathrm{AR}$ at fertilization, whereas $\mathrm{Ni}^{2+}$-sensitive cation channel such as Cav3.2 is critical for the AR induced by an egg envelope component in the toad Bufo arenarum (Krapf et al., 2009). As $\mathrm{Ni}^{2+}$ inhibits the spontaneous AR in C. pyrrhogaster sperm (Fig.1), it is suggested that a signaling pathway mediated by $\mathrm{Ni}^{2+}$-sensitive cation channel is conserved for the AR in the sperm of both species. However, that pathway works at fertilization only in $B$. arenarum. In the fertilization of $C$. pyrrhogaster, Cav3.2 mediates the regulation of sperm motility (Takahashi et al., 2013; Watanabe and Takayama-Watanabe, 2014). Likewise, CatSper 1 participates in both acrosome reaction 
A

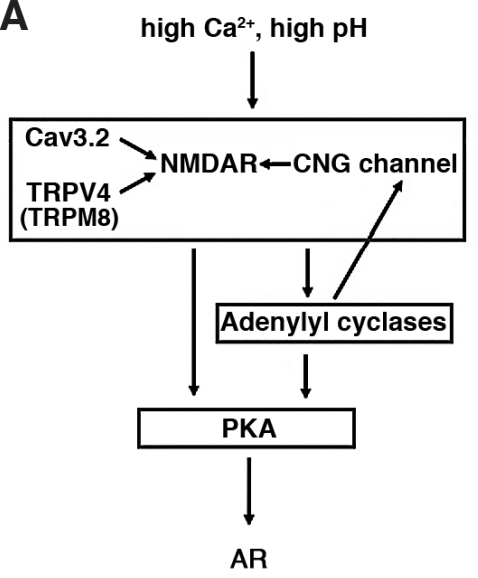

B

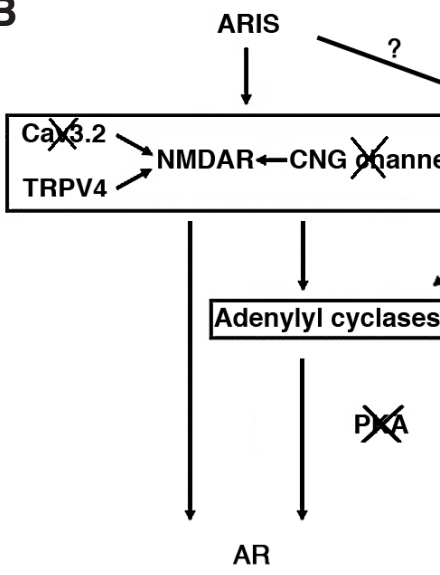

Fig. 6. Signaling pathways of the sperm for spontaneous and ARIS-induced acrosome reaction (AR) in C. pyrrhogaster. (A) Pathways for spontaneous AR. High concentration of $\mathrm{Ca}^{2+}$ and $\mathrm{pH}$ that are equivalent to those in egg jelly gate Cav3.2 orTRPV4 (orTRPM8), cause depolarization of sperm membrane, and gate NMDAR. Influx of $\mathrm{Ca}^{2+}$ through those channels activates adenylyl cyclases and the increased cAMP gates cyclic nucleotide-gated (CNG) channel. $\mathrm{Ca}^{2+}$ further influxed leads to the activation of PKA through adenylyl cyclase-dependent or -independent pathways, and then AR was induced. (B) Pathways for ARIS-induced AR. ARIS gatesTRPV4, causes depolarization of sperm membrane, and gates NMDAR. Ca ${ }^{2+}$ influxed through the channels induces $A R$ through adenylyl cyclase-dependent or -independent pathways. Transmembrane adenylyl cyclase may be activated through a Gprotein. PKA was not needed in the ARIS-induced AR. and motility in human (Tamburrino et al., 2014), although CatSper cation channel is not present in amphibian sperm (Cai and Clapham, 2008). These facts suggest that some $\mathrm{Ca}^{2+}$ permeable channels for the AR are interchangeable with those for the regulation of motility. Such interchangeability of an intracellular signaling mediator is supposed to be a key to develop a new combination of the mediators, resulting in the evolution of the signaling pathway for the AR. Further comparative study about the usages of intracellular mediators will reveal how the multiple pathways for AR in the sperm correlate with the establishment of a variety of signaling pathways working in the fertilization of extant animal species.

\section{Materials and Methods}

\section{Gametes}

The experimental protocol was approved by the Committee for Animal Experiments of Yamagata University (No. 29148). Animals were treated under the Guidelines for the Proper Conduct of Animal Experiments in Japan. Mature eggs were obtained from the uterus, the most posterior region of the oviduct after females were daily injected with 300 IU human chorionic gonadotropin three times. Sperm were collected from the vas deferens.

\section{Egg jelly extract}

Egg jelly extract was prepared according to Kon et al., (2017). Briefly, mature eggs were shaken in Steinberg's salt solution ( $58.2 \mathrm{mM} \mathrm{NaCl}, 0.67$ $\mathrm{mM} \mathrm{KCl}, 6 \mathrm{mM} \mathrm{Ca}\left(\mathrm{NO}_{3}\right)_{2}, 0.83 \mathrm{mM} \mathrm{MgSO}{ }_{4}, 10 \mathrm{mM}$ Tris-HCl: $\mathrm{pH}$ 8.5) for $1 \mathrm{~h}$. The supernatant was collected and then centrifuged at $13,500 \mathrm{rpm}$ at $4^{\circ} \mathrm{C}$ for $30 \mathrm{~min}$. The supernatant was again collected as the JE and stored at $-25^{\circ} \mathrm{C}$ until experimental use.

\section{Chemicals}

Chemicals were purchased from Sigma-Aldrich (Tokyo). Mibefradil (a blocker of T type VDCC; Bezprozvanny and Tsien, 1995; Takahashi et al., 2013), $\mathrm{NiCl}_{2}$ (a selective blocker of Cav3.2; Lee et al., 1999; TakayamaWatanabe et al., 2015), nifedipine (a blocker of $L$ type VDCC; Furukawa et al., 2009; Takayama-Watanabe et al., 2015), RN1734 (a TRPV4 channel blocker; Vincent et al., 2009; Endo et al., 2019), diltiazem (a blocker of CNG channel; Kolesnikov et al., 1990), mdl12330A (an inhibitor of transmembrane adenylyl cyclases; O'brien et al., 2011), or KH7 (an inhibitor of soluble adenylyl cyclase; Bitterman et al., 2013) was used at a final concentration of $100 \mu \mathrm{M}$ (mibefradil, $\mathrm{NiCl}_{2}$, and RN1734), $500 \mu \mathrm{M}$ (MK801), 50 $\mu \mathrm{M}$ (diltiazem), $10 \mu \mathrm{M}$ (mdl12330A), or $5 \mu \mathrm{M}(\mathrm{KH} 7)$. Forskolin (an activator of transmembrane adenylyl cyclase; O'brien et al., 2011), or $\mathrm{NaHCO}_{3}$ (an activator of soluble adenylyl cyclase; Buffone et al., 2014) was used at 10 $\mu \mathrm{M}$ (Forskolin), or $1 \mathrm{mM}\left(\mathrm{NaHCO}_{3}\right)$. $\mathrm{H} 89$ (an inhibitor of PKA; O'brien et al., 2011) was used at $10 \mu \mathrm{M}$.

\section{Acrosome reaction}

Sperm were pretreated with one of the channel blockers or enzyme inhibitors in the reconstructed vas deferens solution $\left(20 \mathrm{mM} \mathrm{NaCl}, 6 \mathrm{mM} \mathrm{Na}_{2} \mathrm{SO}_{4}\right.$, $1 \mathrm{mM} \mathrm{KCl}, 0.1 \mathrm{mM} \mathrm{Ca}\left(\mathrm{NO}_{3}\right)_{2}, 0.06 \mathrm{mM} \mathrm{MgSO}_{4}, 10 \mathrm{mM}$ HEPES- $\mathrm{NaOH}$ $\mathrm{pH}$ 6.9) for $3 \mathrm{~min}$. For the induction of AR by ARIS, sperm were incubated in JE containing the same blocker or inhibitor for $5 \mathrm{~min}$. They were then fixed in $2.5 \%$ glutaraldehyde, and the absence of acrosome in the tip of the sperm head was evaluated in more than 100 sperm using a dark field microscope (CX41; Olympus Co., Tokyo Japan). For spontaneous AR, sperm were incubated in ST containing a blocker or an inhibitor for $1 \mathrm{~h}$ according to Kon et al., (2017). Pretreatment with a chemical was not performed in examining the effect of activators of adenylyl cyclases. Experiments were independently performed at least three times.

\section{Statistics}

Significant differences were evaluated by Welch's $t$-test.

\section{Expression of CNG channel and adenylyl cyclases}

RNAseq data from spermatogenic testes (Watanabe and TakayamaWatanabe, 2014) were surveyed by the BLAST protocol to find a contig with high homology to the CNGB3 subunit of CNG channel and adenylyl cyclases. Reverse-transcription PCR was performed in the spermatogenic and nonspermatogenic testes using specific DNA primers for mRNAs of the CNGB3 (Forward: GGAATCGTCGCATGCAGATGTG, REVERSE: CATTCAGAAAGGCTCATCGCATG), AC3 (Forward: TAACACCAGACTCCAGCACAAAT, Reverse: TCAAGATGTCACGGGTATCCTCC), AC6 (Forward: CAAGGTGGCTCTCAAGTACATGA, Reverse: TGTTCGCTTCCAGCTCTACGTAG), AC9 (Forward: GACTACAGCAGCATTGAGAAGAT, Reverse: TTGGATTCGACACTCCACCCCAG), or AC10 (Forward: GCAAAGCTTAATATCAGACAGCC, Reverse: AAACGTATCAATGTAGTGTGCC) that were designed from the contig base sequences. Expressions of protamine and elongation factor 1 mRNA were examined as the representatives of spermatid-specific and ubiquitous genes (Yokoe et al., 2014).

\section{Acknowledgements}

We thank all members of the Japanese newt research community for valuable comments and discussion. This work was supported by grants from the Japan Society for the Promotion of Science (KAKENHI 15K07165, 16K07459).

\section{References}

AIDLEY, D.J., STANFIELD, P.R. (1996). Other neurotransmitter-gated channels. In Ion Channels. Cambridge University Press, Cambridge, pp. 84-89. 
BARISONE, G.A., HEDRICK, J.L., CABADA, M.O. (2002). Vitelline envelope of Bufo arenarum: biochemical and biological characterization. Biol. Reprod. 66: 1203-1209.

BEZPROZVANNY, I., TSIEN, R.W. (1995). Voltage-dependent blockade of diverse types of voltage-gated $\mathrm{Ca} 2+$ channels expressed in Xenopus oocytes by the Ca2+ channel antagonist mibefradil (Ro 40-5967). Mol. Pharmacol. 48: 540-549.

BITTERMAN, J.L., RAMOS-ESPIRITU, L., DIAZ, A., LEVIN, L.R., BUCK, J. (2013). Pharmacological distinction between soluble and transmembrane adenylyl cyclases. J. Pharmacol. Exp. Ther. 347: 589-598.

BLEIL, J.D., WASSARMAN, P.M. (1980). Mammalian sperm and egg interaction: identification of a glycoprotein in mouse-egg zona pellucidae possessing receptor activity for sperm. Cell 20: 873-882.

BUFFONE, M.G., WERTHEIMER, E.V., VISCONTI, P.E., KRAPF, D. (2014). Centra role of soluble adenylyl cyclase and cAMP in sperm physiology. Biochim. Biophys. Acta 1842: 2610-2620.

CAI, X., CLAPHAM, D.E., (2008). Evolutionary genomics reveals lineage-specific gene loss and rapid evolution of a sperm-specific ion channel complex: CatSpers and CatSper beta. PLOS ONE 3: e3569.

CAMPANELLA, C., CAROTENUTO, R., INFANTE, V., MATURI, G., ATRIPALDI, U. (1997). Sperm-egg interaction in the painted frog (Discoglossus pictus): an ultrastructural study. Mol. Reprod. Dev. 47: 323-333.

CHEN, Y., CANN, M.J., LITVIN, T.N., IOURGENKO, V., SINCLAIR, M.L., LEVIN, L.R., BUCK, J. (2000). Soluble adenylyl cyclase as an evolutionarily conserved bicarbonate sensor. Science 289: 625-628.

CHERR, G.N., CLARK, W.H. (1985). An egg envelope component induces the acrosome reaction in sturgeon sperm. J. Exp. Zool. 234: 75- 85.

CHOI, E.J., XIA, Z., STORM, D.R. (1992). Stimulation of the type III olfactory adenylyl cyclase by calcium and calmodulin. Biochemistry 31: 6492-6498.

DARSZON, A., GUERRERO, A., GALINDO, B.E., NISHIGAKI, T., WOOD, C. (2008). Sperm activating peptides in the regulation of ion fluxes, signal transduction and motility. Int. J. Dev. Biol. 52: 595-606.

DARSZON, A., ACEVEDO, J.J., GALINDO, B.E., HERNÁNDES-GONZÁLEZ, E.O., NISHIGAKI, T., TREVIÑO, C.L., WOOD, C., BELTRÁN, C. (2006). Sperm channel diversity and functional multiplicity. Reproduction 131: 977-988.

ENDO, D., KON, C., SATO, T., TOYAMA, F., KATSURA, Y., NAKAUCHI, Y., TAKAYAMAWATANABE, E., WATANABE, A. (2019). NMDA-type glutamate receptors mediate the acrosome reaction and motility initiation in newt sperm. Mol. Reprod. Dev. doi: $10.1002 / \mathrm{mrd} .23225$.

ETKOVITZ, N., TIROSH, Y,. CHAZAN, R., JALDETY, Y., DANIEL, L, RUBINSTEIN, S., BREIBART, H. (2009). Bovine sperm acrosome reaction induced by G-proteincoupled receptor agonists is mediated by epidermal growth factor receptor transactivation. Dev. Biol. 334: 447-457.

FURUKAWA, T., NUKADA, T., NAMIKI, Y., MIYASHITA, Y., HATSUNO, K., UENO Y., YAMAKAWA, T., ISSIKI, T. (2009). Five different profiles of dihydropyridines in blocking T- type $\mathrm{Ca}^{2+}$ channel subtypes (Cav 3.1 (1G), Cav $3.2(1 \mathrm{H}$ ), and Cav3.3 (11)) expressed in Xenopus oocytes. Eur. J. Pharmacol. 613: 100-107.

HIYOSHI, W., SASAKI, T., TAKAYAMA-WATANABE, E., TAKAI, H., WATANABE, A., ONITAKE, K. (2007). Egg-jelly of the newt, Cynops pyrrhogaster contains a factor essential for sperm binding to the vitelline envelope. J. Exp. Zool. 307A: 301-311.

IKADAI, H., HOSHI, M. (1981). Biochemical studies on the acrosome reaction of the starfish, Asterias amurensis. II. Purification and characterization of acrosome reaction-inducing substance. Dev. Growth Differ. 23: 81-88.

JAISWAL, B.S., CONTI, M. (2003). Calcium regulation of the soluble adenylyl cyclase expressed in mammalian spermatozoa. Proc. Natl. Acad. Sci. USA. 100 10676-10681.

JIN, M., FUJIWARA, E., KAKIUCHI, Y., OKABE, M., SATOUH, Y., BABA, S.A., CHIBA, K., HIROHASHI, N. (2011). Most fertilizing mouse spermatozoa begin their acrosome reaction before contact with the zona pellucida during in vitro fertilization. Proc. Natl. Acad. Sci. USA. 108: 4892-4896.

KOLESNIKOV, S.S., ZHAINAZAROV, A.B., KOSOLAPOV, A.V. (1990). Cyclic nucleotide-activated channels in the frog olfactory receptor plasma membrane. FEBS Lett. 266: 96-98.

KON, S., SATO, T., ENDO, D., TAKAHASHI, T., TAKAKU, A., NAKAUCHI, Y., TOYAMA, F., MEYER-ROCHOW, V.B., TAKAYAMA-WATANABE, E., WATANABE, A. (2017). Sperm storage influences the potential for spontaneous acrosome reaction of the sperm in the newt Cynops pyrrhogaster. Mol. Reprod. Dev. 84: 1314-1322.
KRAPF, D., O'BRIEN, E.D., CABADA, M.O., VISCONTI, P.E., ARRANZ, S.E., (2009), Egg water from the amphibian Bufo arenarum modulates the ability of homologous sperm to undergo the acrosome reaction in the presence of the vitelline envelope. Biol. Reprod. 80: 311-319.

LEE, J.H., GOMORA, J.C., CRIBBS, L.L., PEREZ-REYES, E. (1999). Nickel block of three cloned T-type calcium channels: Low concentrations selectively block alpha-1H. Biophys. J. 77: 3034-3042.

O'BRIEN, E.D., KRAPF, D., CABADA, M.O., VISCONTI, P.E., ARRANZ, S.E. (2011) Transmembrane adenylyl cyclase regulates amphibian sperm motility through protein kinase A activation. Dev. Biol. 350: 80-88.

OKUMURA, H., KOHNO, Y., IWATA, Y., MORI, H., AOKI, N., SATO, C., KITAJIMA, K. NADANO, D., MATSUDA, T. (2004). Anewly identified zona pellucida glycoprotein, $\mathrm{ZPD}$, and dimeric ZP1 of chicken egg envelope are involved in sperm activation on sperm-egg interaction. Biochem. J. 384: 191-199.

PICHERAL, B. (1977). Fertilization in the newt Pleurodeles. II. Penetration of the spermatozoa and the local reaction of the egg. J. Ultrastruct. Res. 60: 181-202.

SASANAMI, T., PAN, J., MORI, M. (2003). Expression of perivitelline membrane glycoprotein ZP1 in the liver of Japanese quail (Coturnix japonica) after in vivo treatment with diethylstilbestrol. J. Steroid Biochem. Mol. Biol. 84: 109-116.

SASANAMI, T., MURATA, T., OHTSUKI, M., MATSUSHIMA, M., HIYAMA, G., KANSAKU, N., MORI, M. (2007). Induction of sperm acrosome reaction by perivitelline membrane glycoprotein ZP1 in Japanese quail (Coturnix japonica). Reproduction 133: 41-49.

SASAKI, T., KAMIMURA, S., TAKAI, H., WATANABE, A., ONITAKE, K. (2002). The activity for the induction of the sperm acrosome reaction localizes in the outer layers and exists in the high-molecular-weight components of the egg-jelly of the newt, Cynops pyrrhogaster. Zygote 10: 1-9.

SEGALL, G.K., LENNARZ, W.J. (1979). Chemical characterization of the component of the egg jelly coat from sea urchin eggs re- sponsible for induction of the acrosome reaction. Dev. Biol. 71: 33-48.

SHUR, B.D. (1999). Zona pellucida-induced signal transduction via sperm surface 11,4-galactosyltransferase. In The male gamete: From basic science to clinical application. (Ed. Gagnon C.). Cache River Press., Vienna, IL, USA, pp.213-225.

TAKAHASHI, T., KUTSUZAWA, M., SHIBA, K., TAKAYAMA-WATANABE, E., INABA, K., WATANABE, A. (2013). Distinct $\mathrm{Ca}^{2+}$ channels maintain a high motility state of the sperm that may be needed for penetration of egg jelly of the newt, Cynops pyrrhogaster. Dev. Growth Differ. 55: 657-667.

TAKAHASHI, S., NAKAZAWA, H., WATANABE, A., ONITAKE, K. (2006). The outermost layer of egg-jelly is crucial to successful fertilization in the newt, Cynops pyrrhogaster. J. Exp. Zool. 305A: 1010-1017.

TAKAYAMA-WATANABE, E., OCHIAI, H., TANINO, S., WATANABE, A. (2015). Contribution of different $\mathrm{Ca}^{2+}$ channels to the acrosome reaction-mediated initiation of sperm motility in the newt Cynops pyrrhogaster. Zygote 23: 342-351.

TAKAYAMA-WATANABE, E., TAKAHASHI, T., YOKOE, M., WATANABE, A. (2014). Acrosome reaction-mediated motility initiation that is critical for the internal fertilization of urodele amphibians. In Sexual Reproduction in Animals and Plants (Eds. Sawada H., Inoue N., Iwano M.) Springer, Tokyo, pp.97-103.

TAMBURRINO, L., MARCHIANI, S., MINETTI, F., FORTI, G., MURATORI, M., BALDI, E. (2014). The CatSper calcium channel in human sperm: relation with motility and involvement in progesterone-induced acrosome reaction. Hum. Reprod. 29: 418-428.

THOMAS, P., MEIZEL, S. (1989). Phosphatidylinositol 4,5-bisphosphate hydrolysis in human sperm stimulated with follicular fluid or progesterone is dependent upon $\mathrm{Ca}^{2+}$ influx. Biochem. J. 264: 539-546.

UEDA, Y., KUBO, H., IWAO, Y. (2003). Characterization of the acrosome reactioninducing substance in Xenopus (ARISX) secreted from the oviductal pars recta onto the vitelline envelope. Dev. Biol. 264: 289-298.

UEDA, Y., YOSHIZAKI, N., IWAO, Y. (2002). Acrosome reaction in sperm of the frog, Xenopus laevis: its detection and induction by oviductal pars recta secretion. Dev. Biol. 243: 55-64.

UKITA, M., ITOH, T., WATANABE, A., ONITAKE, K. (1999). Substances for the initiation of sperm motility in egg-jelly of the Japanese newt, Cynops pyrrhogaster. Zool. Sci. 16: 793-802.

VACQUIER, V.D., LOZA-HUERTA, A., GARCÍA-RINCÓN, J., DARSZON, A., BELTRÁN, C. (2014). Soluble adenylyl cyclase of sea urchin spermatozoa. Biochim. Biophys. Acta 1842: 2621-2628. 
VINCENT, F., ACEVEDO, A., NGUYEN, M.T., DOURADO, M., DEFALCO, J., GUSTAFSON, A., SPIRO, P., EMERLING, D.E., KELLY, M.G., DUNCTON, M.A.J. (2009). Identification and characterization of novel TRPV4 modulators. Biochem. Biophys. Res. Commun. 389: 490-494.

VISCONTI, P.E., STEWART-SAVAGE, J., BLASCO, A., BATTAGLIA, L., MIRANDA, P., KOPF, G.S., TEZÓN, J.G. (1999). Roles of bicarbonate, cAMP, and protein tyrosine phosphorylation on capacitation and the spontaneous acrosome reaction of hamster sperm. Biol. Reprod. 61: 76-84.

WARD, D.R., STOREY, B.T., KOPF, G.S. (1992). Activation of a Gi protein in mouse sperm membranesby solubilized proteins of the zona pellucida, the egg's extracellular matrix. J. Biol. Chem. 267: 14061-14067.

WATANABE, A., FUKUTOMI, K., KUBO, H., OHTA, M., TAKAYAMA-WATANABE, E., ONITAKE, K. (2009). Identification of egg-jelly substances triggering sperm acrosome reaction in the newt, Cynops pyrrhogaster. Mol. Reprod. Dev. 79: 399-406.

WATANABE, A., TAKAYAMA-WATANABE, E. (2014). In silico identification of the genes for sperm-egg interaction in the internal fertilization of the newt Cynops pyrrhogaster. Int. J. Dev. Biol. 58: 873-879.
WATANABE, T., KUBO, H., TAKESHIMA, S., NAKAGAWA, M., OHTA, M., KAMIMURA, S., TAKAYAMA-WATANABE, E., WATANABE, A., ONITAKE, K. (2010). Identification of the sperm motility-initiating substance in the newt, Cynops pyrrhogaster, and its possible relationship with the acrosome reaction during internal fertilization. Int. J. Dev. Biol. 54: 591-597.

WERTHEIMER, E., KRAPF, D., DELA VEGA-BELTRAN, J.L., Sánchez-CÁRDENAS, C., NAVARRETE, F., HADDAD, D., ESCOFFIER, J., SALICIONI, A.M., LEVIN L.R., BUCK, J., MAGER, J., DARSZON, A., VISCONTI, P.E. (2013). Compartmentalization of distinct CAMP signaling pathways in mammalian sperm. J. Biol. Chem. 288: 35307-35320.

YOKOE, M., TAKAYAMA-WATANABE, E., SAITO, Y., KUTSUZAWA, M., FUJITA, K. OCHI, H., NAKAUCHI, Y., WATANABE, A. (2016). A novel cysteine knot protein for enhancing sperm motility that might facilitate the evolution of internal fertilization. PLOS ONE e0160445.

YOKOE, M., SANO, M., SHIBATA, H., SHIBATA, D., TAKAYAMA-WATANABE, E., INABA, K., WATANABE, A. (2014). Sperm proteases that may be involved in the initiation of sperm motility in the newt, Cynops pyrrhogaster. Int. J. Mol. Sci. 15: 15210-15224. 


\section{Further Related Reading, published previously in the Int. J. Dev. Biol.}

Identification of the sperm motility-initiating substance in the newt, Cynops pyrrhogaster, and its possible relationship with the acrosome reaction during internal fertilization

Toshihiko Watanabe, Hideo Kubo, Shinya Takeshima, Mami Nakagawa, Manami Ohta, Saori Kamimura, Eriko Takayama-Watanabe, Akihiko Watanabe, and Kazuo Onitake

Int. J. Dev. Biol. (2010) 54: 591-597

https://doi.org/10.1387/ijdb.092894tw

Sperm penetration through cumulus mass and zona pellucida

Ekyune Kim, Misuzu Yamashita, Masanori Kimura, Arata Honda, Shin-Ichi Kashiwabara and Tadashi Baba

Int. J. Dev. Biol. (2008) 52: 677-682

https://doi.org/10.1387/ijdb.072528ek

Mammalian fertilization:the egg's multifunctional zona pellucida

Paul M. Wassarman and Eveline S. Litscher

Int. J. Dev. Biol. (2008) 52: 665-676

https://doi.org/10.1387/ijdb.072524pw

Mobilisation of stored calcium in the neck region of human sperm - a mechanism for regulation of flagellar activity Kweku Bedu-Addo, Sarah Costello, Claire Harper, Gisela Machado-Oliveira, Linda Lefievre, Christopher Ford, Christopher Barratt and Stephen Publicover

Int. J. Dev. Biol. (2008) 52: 615-626

https://doi.org/10.1387/ijdb.072535kb

Regulation of the starfish sperm acrosome reaction by cGMP, pH, cAMP and Ca2+ Midori Matsumoto, Osamu Kawase, M. Sadiqul Islam, Masahiro Naruse, Shin-Nosuke Watanabe, Riho Ishikawa and Motonori Hoshi

Int. J. Dev. Biol. (2008) 52: 523-526

https://doi.org/10.1387/ijdb.072511mm

\section{Regulating the acrosome reaction}

Harvey M. Florman, Melissa K. Jungnickel and Keith A. Sutton

Int. J. Dev. Biol. (2008) 52: 503-510

https://doi.org/10.1387/ijdb.082696hf

Egg-jelly signal molecules for triggering the acrosome reaction in starfish spermatozoa M Hoshi, T Nishigaki, A Ushiyama, T Okinaga, K Chiba and M Matsumoto Int. J. Dev. Biol. (1994) 38: 167-174

http://www.intjdevbiol.com/web/paper/7981026
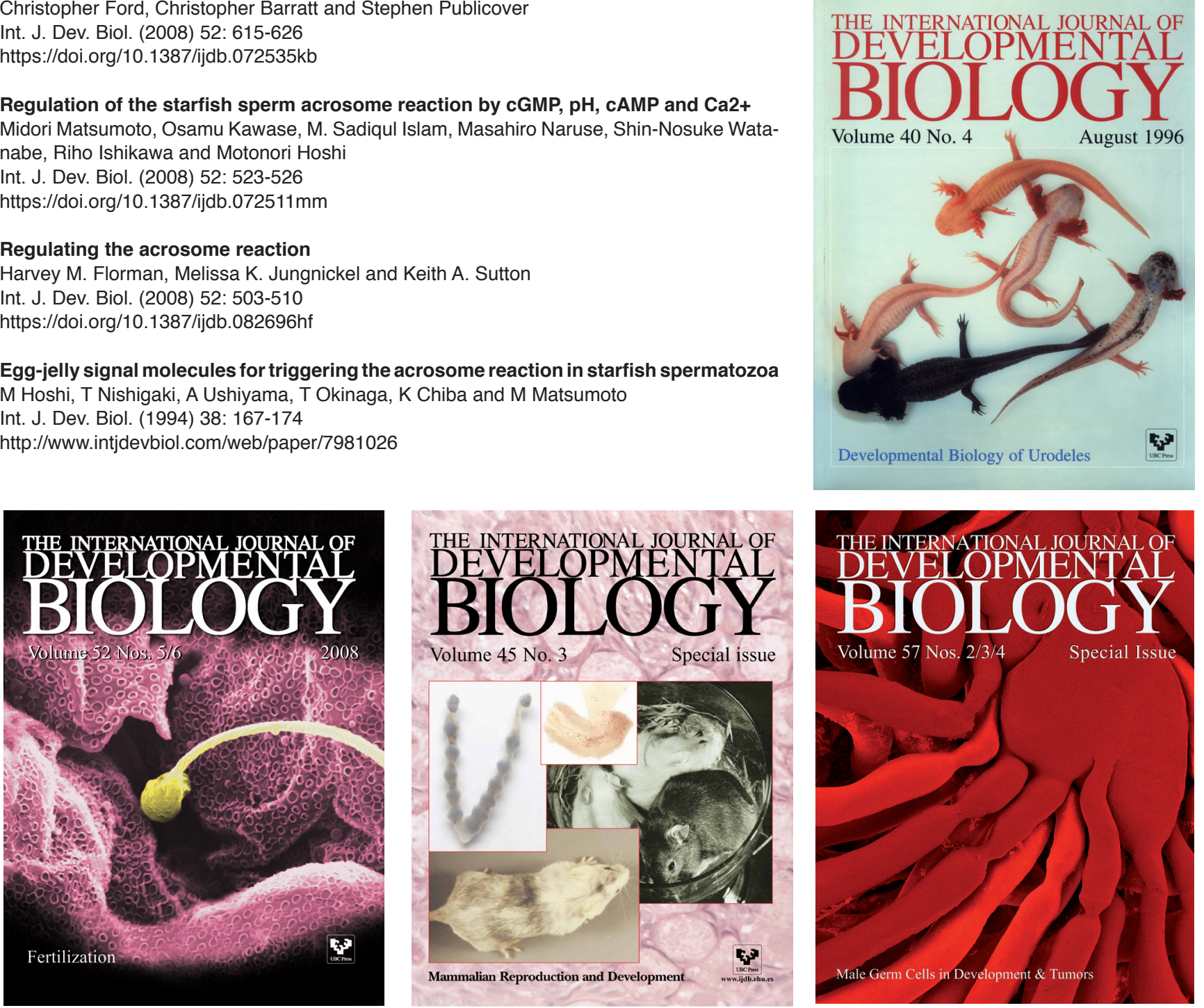